\author{
Jonasz Suchy \\ Uniwersytet Wroclawski \\ jonasz.suchy@tlen.pl
}

\title{
Czy prawo własności nieruchomości w Polsce jest nadal prawem własności?
}

Artykuł nadesłany: 9.12.2016; artykuł zaakceptowany: 15.09.2019

Kody klasyfikacji JEL: A1, B25, B31, B35, K4, P14, P26

Keywords: property, Rothbard, decree, Bierut, expropriation

\section{Abstract \\ Is legal estate in land still legal according to Polish law?}

The aim of the article is to investigate the possibility of implementing Murray Rothbard's concept of absolute property right in Polish civil procedure. The historical background of this reflection is the time of dispossessions and the policies undertaken by the Polish communist government toward rightful owners of immovable property living in post-war Warsaw. The process of dispossessions was based on the edict imposed by the president of Poland at that time, Bolesław Bierut. Therefore, another aim of the study is to examine the results of Bierut's edict, including its substantive and procedural legal effects. Furthermore, the article has shown the advantages of primal ownership rule as a fundamental and arbitrary title to being an owner of real estate as the non-aggression principle would be restored. By taking these assumptions under consideration, the author wants to highlight that the undertaken dispossessions were lawless in the normative as well as ethical view. The logical consequence of the abovementioned philosophy is the thesis that the attitude toward this issue of recent Polish governments, which have not done anything to enable legal owners to get their ownerships back from the state, could not be tolerated as it was also unlawful. Moreover, if the Polish government had acted according to the law, the rightful owners of dispossessed legal estate would have received a convenient way to regain their property as well an opportunity to demand payment and compensation.

By referring to the concept of absolute property right, the author wishes to indicate that each act of dispossession undertaken by using governmental force was unlawful as it could not be justified by ethical rules of natural law. It has also been concluded that it would be worth deliberating the implementation into Polish civil procedure of an institution which would allow owners who had lost their ownership to regain their right to property. Such proceedings would remain valid not just inter partes (between the parties) but also erga omnes (toward all).

The article is also supplemented with a reflection of the economic effects of Bierut's edict while taking into consideration the policy's influence upon the possibility of conducting a rational economic calculation. 


\section{Wstęp}

W dobie prawa pozytywnego, nakreślającego granice wszystkich tworzonych w jego granicach instytucji, przekonanie, że może istnieć prawo własności od tak pojmowanego porządku niezależne, wydaje się wątpliwie. Prawo stanowione bywa uznawane za najlepszą gwarancję tego, iż powstałe w jego ramach stosunki prawne, w tym stosunki własnościowe, będą należycie chronione przez państwo. Prezentowana analiza jest próbą rozważenia kwestii, czy państwo rzeczywiście należycie chroni prawo własności oraz czy źródło tego prawa leży jedynie w aktach prawotwórczych. Tłem owych rozważań są wydarzenia budzące do dzisiaj wiele emocji, których negatywne skutki zarówno ekonomiczne, jak i prawne nadal pozostają nierozstrzygnięte. Tak zwanym dekretem Bieruta, a właściwie dekretem z dnia 26 października 1945 roku o własności i użytkowaniu gruntów na obszarze m. st. Warszawy (Dz.U. z 1945 r. Nr 50, poz. 279), znacjonalizowano bowiem wszystkie grunty, które znajdowały się w przedwojennych graniach miasta. Odbyło się to z pogwałceniem prawa dotychczasowych właścicieli, którzy przymusem państwowym zostali wyzbyci swych uprawnień. W wyniku podjętych wtedy działań wiele gruntów w Warszawie ma do dziś nierozstrzygnięty stan prawny.

\section{Teoretyczny aspekt oraz metodologia badań}

Praca ma na celu przeanalizowanie koncepcji prawa własności absolutnej opracowanej przez Murraya Rothbarda w kontekście postępowania o ustalenie prawa własności w ramach polskiej procedury cywilnej. Tłem historycznym owych rozważań jest okres wywłaszczeń nieruchomości na rzecz Skarbu Państwa na podstawie tak zwanego dekretu Bieruta z uwzględnieniem materialno- i proceduralnoprawnych skutków podjętych wówczas działań. Rozważania zawarte w niniejszym artykule pozostają w bezpośrednim związku z dorobkiem austriackiej szkoły ekonomii oraz teoretycznoprawnymi podstawami koncepcji prawa własności absolutnej wywiedzionymi przez Rothbarda. Nie bez znaczenia dla aktualności pracy są zmiany w ustawie o obrocie nieruchomościami z 2015 roku, jak też wyrok Trybunału Konstytucyjnego z 2016 roku potwierdzający zgodność owych zmian z Konstytucją RP. Nowelizacja ta podtrzymuje skutki prawne dekretu Bieruta, których oceny dokonano w prezentowanej pracy.

W artykule wykorzystano metodę interpretacji dokumentów, w szczególności dokumentów prawnych. Głównym przedmiotem badań był tekst ustawy o obrocie nieruchomościami wraz ze zmianami wprowadzonymi w 2015 roku oraz tekst wyroku Trybunału Konstytucyjnego potwierdzający zgodność owej nowelizacji z Konstytucją. 


\section{Prawo własności absolutnej a prawo naturalne}

Własność od czasów rzymskich jest postrzegana jako główne i najważniejsze prawo rzeczowe. W takim ujęciu podmiotem prawa własności może być każdy, kto nabędzie to prawo legalnie, przedmiotem zaś własności pozostają rzeczy będące w obiegu. Prawo własności zawiera w sobie dwie charakterystyczne funkcje - dodatnią, przejawiającą się w możności dowolnego rozporządzania rzeczą, oraz ujemną, dozwalającą na wykluczenie od wpływu na daną rzecz osób trzecich. W dyskursie filozoficznym istnieją koncepcje, które w swym zamyśle kładą nacisk na nieograniczoność prawa własności i negatywne uprawnienia właścicielskie wynikające ze wspomnianego uprawnienia do wykluczenia osób trzecich od wpływu na określoną rzecz będącą przedmiotem tego prawa.

Do jednej z takich teorii należy koncepcja prawa własności absolutnej stworzona przez Murraya Rothbarda. Koncepcja ta jawi się na tle współczesnych teorii własności jako idea zrywająca z postrzeganiem prawa własności przez pryzmat uprawnień, które należy ograniczać ze względów społecznych, państwowych czy też gospodarczych. Nie oznacza to jednak, iż Rothbard w swych rozważaniach zrywa zupełnie $\mathrm{z}$ dorobkiem doktrynalnym związanym $\mathrm{z}$ tym zagadnieniem. Przeciwnie, stara się on wykazać, zarówno na gruncie etycznym, jak i prawnym, niespójność teorii zakładających, iż prawo własności można ograniczać. Dlatego też tworząc własną definicję owego prawa, skupia się on na jego aspekcie negatywnym, zauważając, iż własność jest prawem naturalnym, zakorzenionym w naturze człowieka i rzeczywistości. W konsekwencji prawo własności mówi przede wszystkim nie o tym, do czego uprawniony jest podmiot będący właścicielem danej rzeczy, lecz o tym, czego inni nie powinni robić w stosunku do rzeczy będącej przedmiotem własności. Tak pojmowane prawo Rothbard uzupełnia o kolejne prawa uniwersalne, takie jak prawo do samoposiadania, dające uprawnienie do dysponowania swoim ciałem i rozporządzania własnym życiem, oraz zasadę pierwotnego zawłaszczenia, mówiącą o tym, że człowiek ma absolutne prawo do sprawiedliwie zawłaszczonych rzeczy. Gwarancją owych praw jest natomiast aksjomat o nieagresji, zakładający, iż każdy człowiek ma niezbywalne prawo do bycia chronionym przed agresją, zarówno ze strony jednostek, jak i państwa (Juruś, 2007, 99-115).

W swoich założeniach Rothbard podkreśla, że główne zagrożenie dla własności prywatnej oraz związanych z nią nieograniczonych uprawnień właściciela stanowi państwo wyposażone w aparat przymusu. Państwo, niczym biblijny Lewiatan, staje się największym agresorem, naruszającym nietykalność osób i ich mienia na masową skalę, jest zatem instytucją immanentnie niemoralną, gdyż swoje dochody pozyskuje siłą. Państwo w takim ujęciu jest złe, ponieważ realizuje interesy jednych kosztem drugich oraz redukuje ilość dobrowolnych relacji. Ponadto państwo, stosując przemoc, legitymizuje ją, stawiając fałszywą alternatywę, 
która każe wybierać pomiędzy dobrem wspólnym a poświęceniem praw poszczególnych jednostek (Juruś 2008, 121-132). Zgodnie jednak z ideą libertariańską głoszoną przez Rothbarda tak pojmowane dobro wspólne nie istnieje, gdyż nie jest ono przedmiotem dobrowolnej zgody wszystkich. W podobny sposób pojęcie dobra wspólnego oraz jego partykularnego wykorzystywania przez rządy państw krytykował Robert Nozick, wskazując na nieuchronną sprzeczność powstającą między prawami jednostek a dobrem wspólnym w chwili podejmowania działań w imię owego dobra czy też sprawiedliwości społecznej. Nozick stwierdza ponadto, że nie ma czegoś takiego jak uzasadnione poświęcenie niektórych z nas dla dobra innych (Nozick, 2016, 25).

Tymczasem, jeśli czyjeś prawa mogą być zagrożone, to właśnie prawa jednostek, gdyż w przeciwieństwie do państwa czy narodu są one bytami realnymi, z przypisaną im godnością i wynikającą z niej niezbywalną wolną wolą. Rothbard zauważa także, że trudno znaleźć prawo człowieka, które nie miałoby swego źródła w prawie własności, dlatego też a minore ad maius, gdy zagrożone jest prawo własności, praktycznie każde prawo z niego wywiedzione staje się jedynie prawem iluzorycznym (Rothbard, 2004, 59). Aby prawo własności miało realną wartość, musi mieć charakter instytucji nieformalnej, niezależnej od władztwa państwowego i opartej jedynie na dobrowolnych umowach pomiędzy ludźmi. W takim kontekście Rothbard kształtuje to prawo w sposób dość oryginalny nawet w ujęciu doktryny praw naturalnych.

Swoiste różnice pomiędzy koncepcją prawa własności absolutnej widoczne są w szczególności na tle doktryn takich filozofów, jak Tomasz z Akwinu czy John Locke (Locke, 1992, XVI). Myśliciele ci uznawali, w przeciwieństwie do Rothbarda, że prawo własności doznaje pewnych ograniczeń. W wypadku Tomasza z Akwinu ograniczenia te podyktowane były przede wszystkim nakazami boskimi i podporządkowaniem władzy duchownej. Z kolei w przypadku doktryny Locke'a ograniczenia w dysponowaniu prawem własności powstają ze względu na prawa stanowione przez państwo, a więc za sprawą praw pozytywnych (Rothbard, 2006, 313, 472). Również przedstawiciele filozofii współczesnej, tacy jak John Rawls czy Lawrence Becker, odrzucają możliwość istnienia absolutnych praw jednostek do sprawiedliwie zawłaszczonych dóbr. W przeciwieństwie do Rothbarda ograniczają oni działania wolnego rynku, akceptując interwencjonizm państwowy. Twierdzą ponadto, że praca nie wystarcza do zyskania absolutnego prawa do rzeczy i nie może być jedynym kryterium dystrybucji własności (Juruś, 2007a, 159-178).

Koncepcja prawa własności absolutnej, będąca instytucją nieformalną, stworzoną w świecie przedpaństwowym, jest równie intrygująca na tle rozważań Thomasa Hobbesa o stanie natury, rozumianym jako wojna każdego z każdym (łac. bella omnium contra omnes). Hobbes stan ten określał mianem świata permanentnego zagrożenia, w którym ze względu na ciągłą niepewność relacji międzyludzkich nie może powstać żadne trwałe prawo. Dopiero wyjście z owego stanu i stworzenie państwa na mocy swoistej umowy społecznej gwarantuje możliwość 
powstania i istnienia takich praw, jak choćby prawo własności (Chojnicka, Olszewski, 2004, 106-108).

Zauważalna w refleksji etycznej antynomia między dwoma wizjami roli państwa i prawa pozytywnego prowadzi do wniosku, iż prawo własności powstaje w realiach przedpaństwowych. Samo powstanie władztwa z kolei może stanowić próbę zawłaszczenia istniejących, dobrowolnych stosunków własnościowych pomiędzy jednostkami, a nie ich realną ochronę. Dzieje się tak ze względu na fakt, iż to właśnie państwo dysponuje silniejszym aparatem przymusu od jakiejkolwiek jednostki czy nawet zbioru jednostek. Dlatego Rothbard w przeciwieństwie do Hobbesa w powstaniu państwa upatruje początek wojny między stanem naturalnym a porządkiem pozytywnym, a źródło owego konfliktu sytuuje w dążeniu władzy państwowej do zawładnięcia siłą, za pomocą powstałych w drodze dobrowolnych umów, stosunkami własnościowymi (Rothbard, 2010, 86).

Przyjęcie danej koncepcji filozoficznej, w ramach której definiowane są poszczególne uprawnienia właścicielskie, ma wpływ nie tylko na sferę rozważań prakseologicznych, lecz także na warunki gospodarowania dobrami będącymi przedmiotem prawa własności. Warto przy tym zauważyć, iż charakter własności określonych dóbr w znaczącym zakresie determinuje możliwość prowadzenia racjonalnej kalkulacji ekonomicznej. W przypadku nieruchomości zasada ta, choć w mniej oczywisty sposób, zachowuje aktualność, co oznacza, że gospodarowanie nieruchomościami pozostającymi w prywatnych rękach i tymi będącymi przedmiotem własności publicznej będzie się w istotny sposób różniło (Juruś, 2010, 201-209). Jak zauważa Ludwig von Mises, w systemie opartym na prywatnej własności rachunek wartości prowadzony jest z konieczności przez każdego członka społeczeństwa. Poszczególne jednostki podejmują decyzje, mając na celu określony wynik swoich działań, który można wycenić w obiektywny czy też intersubiektywny sposób. Jednostki, dokonując wyboru pomiędzy spełnieniem jednej potrzeby kosztem drugiej, dokonują eo ipso sądu wartościującego. Początkowo sądy takie dotyczą bezpośrednio zaspokojenia samej potrzeby, a dopiero później daje to podstawę do oceny dóbr niższego i następnie wyższego rzędu. Dokonywanie owych decyzji w sposób racjonalny jest jednak możliwe tylko wtedy, gdy wszystkie dobra związane z procesem produkcji mogą być sprowadzone do pieniądza, a więc do uniwersalnego miernika wartości. Można zatem uznać, że prywatni właściciele gruntów, ale i budynków, będą działać zgodnie z zasadami racjonalnej kalkulacji ekonomicznej, o ile zostanie spełniona zasada wolnego gospodarowania dobrami, a co za tym idzie realna będzie pieniężna wycena tych dóbr (Mises, 2011, 43-46).

W wypadku natomiast istnienia własności publicznej wszelkie kalkulacje pozostają w rękach urzędników, którzy z założenia wiedzą, jakie cele ma osiągnąć gospodarka, a raczej jedynie tak im się wydaje. Zadanie urzędników polega więc na takim regulowaniu procesów gospodarczych, by osiągnąc dany cel możliwie najmniejszym kosztem. Aby określić najmniej i najbardziej opłacalne rozwiązania, muszą posłużyć się rachunkiem gospodarczym. Rachunek ten jest jednak 
tylko rachunkiem wartości, którego nie da się powiązać z obiektywną wartością dóbr i usług, jako że owe dobra in extenso należą również do własności publicznej. Dlatego też w państwie socjalistycznym każda zmiana gospodarcza staje się przedsięwzięciem, którego rezultatów nie sposób przewidzieć z perspektywy czasu. Należy zatem zaznaczyć, że również gospodarowanie gruntami i budynkami będącymi własnością publiczną jest $\mathrm{z}$ ekonomicznego punktu widzenia nieracjonalne, gdyż w miejsce konkretnego właściciela pojawia się mglista sieć podmiotów państwowych, których cele i decyzje nie będą determinowane prowadzeniem racjonalnego rachunku ekonomicznego (Mises, 2011, 48-50).

Na ułomności systemu własności publicznej nieruchomości wskazuje również Hans Herman Hoppe. Na przykładzie dróg publicznych zauważa on, że własność publiczna powoduje nowe konflikty w obszarach, w których wcześniej ich nie było. Prywatni właściciele domów, ogrodów i pól leżących przy drodze, by móc dalej postępować tak jak poprzednio, muszą płacić właścicielowi drogi opłaty za jej użytkowanie, czyli po prostu podatki. Właściciel drogi uzyskuje w ten sposób kontrolę nad ich prywatną własnością. Prywatni właściciele tracą wyłączność kontroli nad sposobem wykorzystania własnych domów. Właściciel drogi sąsiadującej z domem może wpływać na decyzje dotyczące czyjegoś domu. Może na przykład wymóc na właścicielu domu, by robił albo nie robił czegoś, jeżeli nadal chce wychodzić i przychodzić do domu. Właściciel drogi publicznej ma możliwość ograniczania praw własności prywatnej, a nawet ich całkowitej eliminacji, czyli wywłaszczenia. Nieuniknionym rezultatem będą wszechobecne konflikty. W tym ujęciu własność publiczna nie tylko zatem powoduje problemy w zakresie racjonalnego gospodarowania określonymi dobrami, lecz także jest - w przeciwieństwie do własności prywatnej — źródłem konfliktów między podmiotami państwowymi a poszczególnymi jednostkami (Hoppe, 2011).

\section{Dekret Bieruta}

Okres wczesnych lat Polskiej Rzeczypospolitej Ludowej bez wątpienia nie stwarzał warunków do istnienia własności prywatnej, a wręcz własność tę, jako wytwór kultury burżuazyjnej, programowo zwalczał. Jednym z przejawów zwycięskiego pochodu rewolucji, zmierzającego w stronę nowego wspaniałego świata, był tak zwany dekret Bieruta, a właściwie Dekret o własności i użytkowaniu gruntów na obszarze miasta stołecznego Warszawy wydany w dniu 26 października 1945 roku przez Krajową Radę Narodową (KRN), której prezydentem był Bolesław Bierut. Skutkiem wejścia dekretu w życie było przejęcie wszystkich gruntów w granicach miasta przez gminę miasta stołecznego Warszawy w 1950 roku w związku ze zniesieniem samorządu terytorialnego przez Skarb Państwa. Dekret uzasadniono racjonalnym przeprowadzeniem odbudowy stolicy i dalszą jej rozbudową zgodnie z potrzebami narodu (Gdesz, 2012, 19-25). 
Akt ten w założeniach miał ułatwić odbudowę Warszawy, zwłaszcza tych dzielnic, które najbardziej ucierpiały w wyniku działań wojennych. Teoretycznie nie dotyczył on jednak budynków, a jedynie gruntów, ponieważ budynki przynależące do gruntów, przynajmniej formalnie, pozostawały własnością dotychczasowych właścicieli. Już ta koncepcja powinna była budzić zastrzeżenia, gdyż jest niezgodna z obowiązującą ówcześnie, a także obecnie rzymską zasadą superficies solo cedit, w myśl której własność nieruchomości lokalowej przechodzi na nabywcę wraz z przejściem na niego prawa własności gruntu. W aktualnym porządku prawnym zasada ta jest zawarta w art. 48 oraz 191 Kodeksu cywilnego (Herman, 2010, 23).

Praktycznie jednak zabierano właścicielom również kamienice lub poddawano je obowiązkowi kwaterunku. Wskutek dekretu mieszkańcy Warszawy utracili od 20 do 40 tys. nieruchomości, co mogło stanowić nawet 94\% nieruchomości miasta w przedwojennych granicach. Całość odebranego dekretem mienia szacowana jest na około $40 \mathrm{mld}$ zł (Białogłowski, Dybka, 2014, 15-19).

W miejsce własności gruntów dekret przewidywał wieczystą dzierżawę albo odszkodowanie w miejskich papierach wartościowych. Skalę wywłaszczeń podkreśla fakt, że na blisko 24330 budynków i 40 tys. prywatnych gruntów miasto miało wcześniej zaledwie 853 nieruchomości. W latach 2011 i 2012 miasto zapłaciło łącznie ponad $415 \mathrm{mln}$ zł odszkodowań za nieruchomości dekretowe. Z kolei w 2013 roku w Warszawie toczyło się około 8 tys. postępowań dotyczących dekretu Bieruta (Gronkiewicz-Waltz, 2011). Dekret ten, ze względu na fakt, iż został wydany i zrealizowany niezgodnie z zasadami prawa, doprowadził w konsekwencji do nieuzasadnionej zmiany stosunków własnościowych, które nadal nie zostały w pełni uregulowane, przez co pozostają źródłem kolejnych roszczeń byłych właścicieli wywłaszczonych na podstawie owego aktu. Ponadto współczesne państwo polskie wydaje się niechętne w rozwiązaniu omawianego problemu, co więcej — w 2015 roku zostały uchwalone zmiany, które wpisują się w etatystyczny kontekst wydarzeń sprzed ponad 70 lat.

\section{Stan faktyczny i prawny}

W ramach nowelizacji ustawy o gospodarce nieruchomościami wprowadzono regulację, w myśl której miasto stołeczne Warszawa będzie miało prawo pierwokupu gruntu od nabywcy roszczenia (właściciela gruntu wywłaszczonego dekretem Bieruta) po cenie z nim ustalonej. Mowa o gruntach związanych z budynkami użyteczności publicznej. Rozwiązanie to ma zabezpieczyć interesy mieszkańców Warszawy i nie dopuścić do likwidacji takich placówek jak szpitale czy szkoły. Zgodnie z nowelą w wypadku takich gruntów będzie możliwość odmówienia ich zwrotu w naturze, ustawa zatem expresis verbis odmawia właścicielowi zwrotu nieruchomości ze względu na tak zwane dobro publiczne (Dz.U. z 1997 r. Nr 115, 
poz. 741). Z kolei w 2016 roku wskazaną nowelizację Trybunał Konstytucyjny uznał za zgodną z Konstytucją (OTK K6/14).

W przywołanych rozwiązaniach pobrzmiewają reminiscencje epoki kolektywnych zależności, zbudowanych na marksistowskim przekonaniu, że to byt określa świadomość. Trudno nie ulec również wrażeniu, iż etycznym uzasadnieniem utrzymywania sprzecznych z prawem stosunków własnościowych pozostaje wiara, że dla wyższych wartości, takich jak dobro społeczne, można poświęcić prawa jednostek.

Warto zauważyć, że nawet obecne regulacje dotyczące prawa własności w polskim prawie cywilnym zakładają, zgodnie z art. 140 k.c., ograniczenie prawa własności ze względu na zasady współżycia społecznego oraz społeczno-gospodarcze przeznaczenie prawa. Jest tak mimo faktu, iż w jednym z wyroków Trybunał Konstytucyjny stwierdza, że prawo własności traktowane jest w naszym systemie prawnym jako prawo podmiotowe o najszerszej treści i w porównaniu z innymi prawami jako prawo najsilniejsze w stosunku do rzeczy (OTK I/93). W większości jednak linia orzecznicza skupiona jest wokół twierdzenia, że ustalenie granic swobody korzystania z rzeczy własnej, a w konsekwencji i granic ochrony prawa własności jest przeciwstawieniem się pojmowaniu tego prawa jako prawa absolutnego. Prawo własności jest tym szczególnym prawem, które zapewnia właścicielowi dopuszczalną $\mathrm{w}$ danych warunkach pełnię uprawnień względem rzeczy. Właścicielowi wolno zatem czynić ze swoją rzeczą wszystko, co nie jest zabronione przez ustawy, zasady współżycia społecznego i co nie pozostaje w sprzeczności ze społeczno-gospodarczym przeznaczeniem prawa (III CZP 36/97). Ogólnie zatem do istoty prawa własności w polskim prawie cywilnym należą, z jednej strony, swoboda korzystania z rzeczy własnej, pobieranie z niej pożytków i rozdysponowywanie ją, z drugiej zaś - pewne ograniczenia tej swobody, stanowiące swoistą granicę istoty prawa własności, a także granice ochrony tego prawa. Granice takie, określające swobodę korzystania z rzeczy własnej, a idąc za tym także granice ochrony własności, nie mogą być utożsamiane z ograniczeniami rzeczywistymi, które są przeważnie ustanawiane na rzecz osób trzecich. Do owych ograniczeń należą kolejno: służebność, użytkowanie czy dzierżawa. Celem ustanowienia tego rodzaju granic ochrony mają być zarówno względy ogólne, jak i swobodne korzystanie z rzeczy. Takie ukształtowanie prawa własności w obawie przed tym, by nie zostało przekształcone w ius infinitum, sprawia, że staje się ono, z powodu przedmiotowych ograniczeń, prawem, które explicite określane jest mianem bezwzględnego nieograniczonego prawa podmiotowego do rzeczy, implicite stając się prawem de facto warunkowym i ograniczonym.

\section{Postępowanie o ustalenie utraconego prawa}

Biorąc zatem pod uwagę zarówno prawne, jak i ekonomiczne skutki wywłaszczeń gruntów warszawskich oraz fakt, że wywłaszczenie to stoi w sprzeczności z zasadami etyki wywiedzionymi z prawa naturalnego, należałoby wnioskować, 
że utrzymywanie w mocy skutków prawnych tych działań przez obecne państwo polskie jest równie nieetyczne. Powstaje zatem pytanie, czy można stan ten nadal tolerować, nazywając jednocześnie III RP demokratycznym państwem prawnym? Dotychczasowe działania władz, w szczególności wspomniana nowelizacja ustawy o gospodarce nieruchomościami z 2015 roku, sugerują, że obecne państwo polskie jest przede wszystkim nie państwem prawa, a państwem urzeczywistniającym zasady sprawiedliwości społecznej.

Warto podkreślić, że obecne instytucje prawne nie dają praktycznie możliwości przywrócenia utraconego tytułu własności, a więc de facto odbierają prawowitym właścicielom prawo do odzyskania sprawiedliwie zawłaszczonej rzeczy. W wypadku gdy na mocy dekretu Bieruta właściciel został pozbawiony prawa do nieruchomości, a wszelkie dowody na to, że był właścicielem, takie jak na przykład wpis w księdze wieczystej czy umowa darowizny, zaginęły bez jego winy, to taki podmiot pozostaje trwale pozbawiony należnego prawa. Jedyną instytucją umożliwiającą przywrócenie utraconego prawa jest postępowanie o ustalenie istnienia lub nieistnienia stosunku prawnego lub prawa, unormowane w artykule 189 k.p.c. Artykuł ten mówi, iż każdy, kto ma interes prawny, może żądać ustalenia przez sąd istnienia lub nieistnienia stosunku prawnego lub prawa. Przesłankami dopuszczającymi powództwo o ustalenie jest wykazanie interesu prawnego oraz istnienie stosunku prawnego lub prawa, którego powództwo dotyczy. W przypadku nieistnienia takich przesłanek powództwo podlega oddaleniu. Przesłanki te nie mają charakteru formalnego, lecz materialnoprawny, a więc nie można ich uzupełnić jako braków formalnych. Powództwo można wnieść w każdym czasie i nie ulega ono przedawnieniu, choć przedawniają się same roszczenia, które mogą wynikać ze stosunku prawnego. Z kolei potwierdzeniem, że powód ma interes prawny we wniesieniu powództwa, jest niepewność co do stanu prawnego lub prawa, która ma charakter obiektywny. Co więcej, interes ten musi być zgodny z zasadami współżycia społecznego. Powód może również wystąpić z powództwem, gdy jego prawo nie zostało jeszcze naruszone. Natomiast w przypadku, w którym prawo powoda zostało już wprawdzie naruszone, ale z naruszenia tego mogą wyniknąć jeszcze dalsze skutki, których na razie nie można przewidzieć, na przykład wyrządzenie szkody czynem niedozwolonym, można żądać świadczenia oraz ustalenia odpowiedzialności za szkody mogące powstać w przyszłości.

Postępowanie to napotyka jednak na liczne ograniczenia. Przede wszystkim w drodze tego postępowania nie jest dopuszczalne wytoczenie powództwa, w którym powód domagałby się od sądu, by ten ustalił fakt, właściwość jakiejś rzeczy czy związek przyczynowy pomiędzy dwoma faktami. Można jednak ustalić fakt mający charakter prawotwórczy, jeżeli zmierza on w istocie do ustalenia prawa lub stosunku prawnego. Ponadto orzeczenie wydane w drodze tego postępowania ma charakter jedynie deklaratoryjny, a więc nie będzie miało znaczenia, gdy nie istnieje tytuł własności, który został utracony w wyniku zaistnienia siły wyższej. Co więcej, wyrok ma moc jedynie inter partes, a więc wiąże jedynie strony, które występowały w postępowaniu. Zatem gdyby nawet strona na mocy danego wyro- 
ku uzyskała potwierdzenie istnienia prawa własności, to nie mogłaby się bronić przed roszczeniami podmiotów, które nie brały udziału w przedmiotowym postępowaniu (Broniewicz, Kunicki, Marciniak, 2014, 26-28).

Aby przywołane postępowanie mogło być wykorzystane w przypadku osób, które zostały poszkodowane w wyniku działań podjętych na podstawie dekretu Bieruta, należałoby wprowadzić zmiany w samej konstrukcji tej instytucji. Przede wszystkim wyrok zapadły w takim postępowaniu powinien mieć charakter konstytutywny, tak aby stanowił podstawę do odzyskania utraconego tytułu własności. Ponadto sąd powinien być również uprawniony do ustalania faktów, stosując przesłankę ich prawotwórczości jedynie akcesoryjnie. Dzięki temu podmioty, które utraciły sprawiedliwie nabyte prawo własności, będą miały realną szansę jego odzyskania, gdyż taki wyrok mógłby podlegać wykonaniu w drodze postępowania egzekucyjnego po nadaniu mu klauzuli wykonalności.

Proponowane zmiany stanowią jedną z możliwości przywrócenia naturalnych stosunków własnościowych, które zostały zaburzone w wyniku agresywnych działań władztwa państwowego. Rozwiązanie to bazuje ponadto na przekonaniu, iż państwo w swych działaniach powinno opierać się przede wszystkim na wskazaniach prawa, wspartych o etyczny paradygmat wywiedziony z zasad porządku naturalnego. Porządku, w którym każdy akt wywłaszczenia przy użyciu państwowego aparatu przymusu jest ze swej natury bezprawny. Stanowi wreszcie podstawę do tego, by państwo, które zobowiązało się do równej ochrony prawnej własności, wypełniło nałożone na siebie obowiązki względem obywateli. Przyjęcie natomiast koncepcji prawa własności absolutnej jako podstawy do ochrony własności także sensu largo jest gwarancją zabezpieczenia przedmiotowej własności również w wypadku prób wywłaszczenia z użyciem władztwa państwowego. W takim ujęciu własność jako zarówno instytucja prawna, jak i podstawowe pojęcie związane doktrynami skupionymi wokół idei wolnego rynku wydaje się dodatkowo w pełni realizować swoją istotę, którą jest skupienie w rękach właściciela całości przysługujących mu praw. Dzięki realizacji wskazanych założeń także sam obrót nieruchomościami zyskuje na pewności oraz stabilności, co dodatkowo wspierałoby prowadzenie w tym zakresie racjonalnej kalkulacji ekonomicznej.

\section{Analiza wyników badań oraz wnioski}

Analiza przeprowadzona $\mathrm{w}$ ramach zaprezentowanej pracy prowadzi do wniosku, iż obecnie nie istnieje instytucja prawna pozwalająca na odzyskanie utraconego w wyniku dekretu Bieruta tytułu własności. Ponadto należy podkreślić, że obecny stan prawny nie sprzyja stabilności obrotu nieruchomościami warszawskimi. W ujęciu ekonomicznym z kolei podjęte nowelizacje prawa dalekie są od modelu wolnorynkowego, co więcej — sprzyjają one etatystycznym rozwiązaniom, tym 
samym utrudniając prowadzenie racjonalnej kalkulacji ekonomicznej w zakresie obrotu przedmiotowymi nieruchomościami. W kontekście rozważań teoretycznoprawnych trzeba podkreślić, iż obecne rozumienie prawa własności w polskim prawie znacząco ogranicza uprawnienia właścicielskie. Stawia to pod znakiem zapytania możliwość właściwego korzystania z owych uprawnień, jak też ich ochrony w wypadku sporu prywatnego właściciela nieruchomości objętej przepisami dekretu Bieruta, z podmiotem państwowym. Dlatego też proponowane przyjęcie założeń wynikających z prawa własności absolutnej Rothabrda wydaje się najlepszym oraz zgodnym z refleksją etyczną rozwiązaniem. Chroniłoby to w znacznie szerszym zakresie właściciela oraz potwierdzało jego uprawnienia do przedmiotu własności. Realizacją owego prawa miałoby być z kolei wskazane postępowanie o przywrócenie utraconego tytułu własności. Natomiast gwarancją respektowania ustaleń poczynionych $\mathrm{w}$ wyniku owego postępowania byłoby postanowienie sądu mające charakter erga omnes, a nie jedynie inter partes.

\section{Bibliografia}

\section{Literatura}

Białogłowski, W., Dybka, R. (2014). Dekret o własności i użytkowaniu gruntów na obszarze miasta stołecznego Warszawy. Komentarz. Warszawa: Wolters Kluwer Polska.

Broniewicz, W., Kunicki, I., Marciniak, A. (2014). Postępowanie cywilne w zarysie. Warszawa: Wolters Kluwer Polska.

Chojnicka, K., Olszewski, H. (2004). Historia doktryn politycznych i prawnych. Poznań: Ars boni et aequi.

Gdesz, M. (2012). Rewindykacja gruntów warszawskich. Zagadnienia administracyjnoprawne. Warszawa: Lexis Nexis.

Gronkiewicz-Waltz, H. (5.08.2011). Plac Defilad kolorowy od roszczeń. Gazeta Wyborcza. Data dostępu: 13.11.2016, http://warszawa.wyborcza.pl/warszawa/1,54420,10065497,Gronkiewicz Waltz_plac_Defilad_kolorowy_od_roszczen.html.

Herman, A. (2010). Od PK WN do własnóści. Restytucja mienia przejętego dekretem reformy rolnej. Warszawa: Wydawnictwo Nowy Świat.

Hoppe, H. H. (12.09.2011). O własności prywatnej, wspólnej i publicznej, z uzasadnieniem całkowitej prywatyzacji. Data dostępu: 13.11.2016, https://mises.pl/blog/2011/09/12/hoppe-o-wlasnosci-prywatnej-wspolnej-i-publicznej-z-uzasadnieniem-calkowitej-prywatyzacji/.

Juruś, D. (2007a). Ekonomiczne i etyczne podstawy libertarianizmu. Kraków: Wydawnictwo Naukowe Papieskiej Akademii Teologicznej.

Juruś, D. (2007b). Wokół własności. Próba uporządkowania stanowisk w filozofii i polityce. Analiza i egzystencja. Kraków: Wydawnictwo Naukowe Papieskiej Akademii Teologicznej.

Juruś, D. (2008). Władza na własność. W W. Zuziak, J. Byrska, Wolność i władza w życiu publicznym (201-209). Kraków: Wydawnictwo Naukowe Papieskiej Akademii Teologicznej.

Juruś, D. (2010). Od „dobra wspólnego” do wspólnego zła. W D. Probucka (red.), Dobro wspólne (121-132). Kraków: Wydawnictwo Naukowe Papieskiej Akademii Teologicznej.

Locke, J. (1992). Dwa traktaty o rzadzie. Warszawa: PWN.

Mises, L. von (2011). Kalkulacja ekonomiczna w socjalizmie. Warszawa: Instytut im. Ludwiga von Misesa.

Ekonomia - Wroclaw Economic Review 25/3 (2019)

(C) for this edition by CNS 
Nozick, R. (2016). Anarchia, państwo i utopia. Warszawa: Aletheia.

Rothbard, M. (2004). O nowa wolność. Warszawa: Instytut im. Ludwiga von Misesa.

Rothbard, M. (2006). Economic Thought Before Adam Smith: An Austrian Perspective on the History of Economic Thought. Auburn: Ludwig von Mises Institute.

Rothbard, M. (2010). Etyka wolności. Warszawa: Fijorr Publishing.

\section{Orzeczenia i akty prawne}

Dekret z dnia 26 października 1945 roku o własności i użytkowaniu gruntów na obszarze m. st. Warszawy, Dz.U. z 1945 r. Nr 50, poz. 279.

Uchwała Sądu Najwyższego z dnia 28 sierpnia 1997 roku, sygn. akt III CZP 36/97.

Uchwała Trybunału Konstytucyjnego z dnia 27 września 1994 roku, sygn. akt W 10/93.

Ustawa z dnia 21 sierpnia 1997 roku o gospodarce nieruchomościami, Dz.U. z 1997 r. Nr 115, poz. 741.

Wyrok Trybunału Konstytucyjnego z dnia 23 listopada 2016 roku, sygn. akt K 6/14. 